\title{
Knowledge and culture: two significant issues for local level development programme analysis
}

\author{
Conhecimento e cultura: dois importantes pontos para analisar programas de \\ desenvolvimento em nível local
Connaissance et culture: deux points importants pour analyser les programmes de développement au niveau local

\author{
Conocimiento y la cultura: dos puntos importantes para analizar los programas de desarrollo \\ a nivel local
}

\author{
Ana Maria de Albuquerque Vasconcellos* \\ (annavasc@unama.br) \\ Mário Vasconcellos Sobrinho* \\ (mariovasc@ufpa.br)
}

Recebido em 22/11/2013; revisado e aprovado em 15/01/2014; aceito em 22/02/2014

\begin{abstract}
The paper aims to propose a theoretical framework to analyse development programmes acting at local level. Particularly, the paper stresses two key concepts that should be taken into account in the process of implementing development programme at local level, namely knowledge and culture. The paper shows that understanding of knowledge as a social construction contrasts with the rational, positivist view of knowledge derived exclusively from a scientific viewpoint. The paper explains if development relates to increasing or improving people living standards through social and economic changes, then it will impact on, and be mediated through knowledge and culture.
\end{abstract}

Key words: Knowledge. Culture. Local Development Programmes.

Resumo: O artigo objetiva propor um arcabouço teórico para analisar programas de desenvolvimento e suas ações em nível local. Em particular, o artigo destaca dois conceitos-chave que devem ser levados em consideração no processo de implementação de programas de desenvolvimento em nível local: conhecimento e cultura. O artigo mostra que o entendimento do conhecimento enquanto construção social contrasta com a perspectiva racional e positivista de que este é derivado exclusivamente da ciência. O artigo mostra que se desenvolvimento é relacionado para a melhoria das condições de vida das pessoas por via de mudanças econômicas e sociais, então, desenvolvimento é mediado e impacta sobre conhecimento e cultura.

Palavras-chave: Conhecimento. Cultura. Programas de Desenvolvimento Local.

Résumé: L'article a pour objectif de proposer un cadre théorique pour analyser les programmes de développement et les actions qui en résultent au niveau local. En particulier, l'article identifie trois concept-clés qui doivent être pris en considération dans la cadre de la mise en oeuvre des programmes de développement au niveau local : les concepts de connaissance et de culture. L'article montre que le fait d'appréhender la connaissance comme construction sociale contraste avec une perspective rationnelle et positiviste en vertu de laquelle la connaissance serait exclusivement le résultat de la science. L'article montre que le développement est lié à de meilleures conditions de vie des personnes à partir de changements économiques et sociaux ; à ce titre, le développement a une influence et produit des effets sur la connaissance et sur la culture.

Mots-clés: Connaissance. Culture. Programme de développement local.

Resumen: El artículo objetiva proponer un marco teórico para analizar los programas de desarrollo y sus acciones a nivel local. En particular, el artículo destaca dos conceptos claves que deben ser considerados en el proceso de implantación de programas de desarrollo a nivel local: el conocimiento y la cultura. El artículo muestra que la comprensión del conocimiento como una construcción social contrasta con la perspectiva racional y positivista de que se deriva exclusivamente de la ciencia. El artículo muestra que el desarrollo está relacionado con la mejoría de las condiciones de vida de las personas a través de los cambios económicos y sociales, así, desarrollo es mediado y impacta en el conocimiento y cultura.

Palabras clave: Conocimiento. Cultura. Programas de desarrollo local.

\section{Introduction}

The goal of this paper is to put forward a theoretical framework proposal to examine how development programme acts at local level. Local in this text is conceived as the space where various kinds of knowledge interact and are mediated by developing policy through participatory approaches. The theoretical framework proposal involves two key concepts, namely knowledge and culture. Knowledge and culture have been part of

\footnotetext{
* Universidade Federal do Pará, Belém, Pará, Brasil.
} 
social development debates for decades however the question is how these core concepts have been incorporated into the development programme at local level debates. It implies that the sets of power relations between development government policies and community development are a new challenge in the analysis of how government empowers people and makes them more effective at meeting their development needs.

This paper is organised into three sections aside this introduction and the conclusion. The first section stresses on the concept of knowledge. The aim of the first section is to show how the concept of knowledge has been debated in the context of development. The second section explores the meaning of culture and how it has been examined into development approaches. Then, the third section makes the link between the concepts of knowledge and culture in order to show how they are significant for local level development examination.

\section{Understanding the debate on Knowledge in Development Context}

Knowledge, viewed from a social construction approach emphasises that individuals and collective groups are continually constructing and reinventing their understanding of themselves and the world around them (JACOBS, 2002). Individuals are socialised into a system of beliefs, norms of behaviour and institutions. Reality is constructed through human activity as a product of socialisation (LONG, 1992; JACOBS, 2002; KUKLA, 2000). Members of a society invent together the properties of the world and their life experience through the socialisation process. The term social construction means that reality is built from a set of ideas through which a system of practices is implemented. As was argued by Long (1992, p. 25), all societies implement different life styles, culture forms and rationalities which members utilize in their search for order and meaning, and which they themselves play a part in affirming or restructuring. A focus on local-level analysis brings an awareness of which forms of participation work in specific spaces to provide people with the opportunity to realise inclusive, active citizenship (GAVENTA, 2004).
The influence of the social constructivist's view of knowledge implies that knowledge is a human product, and that it is socially and culturally constructed (KOTHARI, 2001, p. 148). It points to the notion that individuals create meaning through their interactions with each other and with the environment they live in. However, it does not take place only from the perspective of an individual (MUTEBI, 2004).

As Long (1992, p. 25) argued, however, the individual is transmuted metaphorically into the social actor, which signifies the fact that the social actor is a social construction rather than simply a synonym for the individual or a member of Homo sapiens. Social constructivism emphasizes the importance of the knowledge, beliefs, and skills that individuals bring to the experience of learning (BOUWEN; TAILLIEU, 2004). Reality can be also learned collectively leading to an increased capacity to manage change. There is a certain skill involved in the ability to analyse the learner's previous knowledge as a way of enhancing the learning of new knowledge (MUTEBI, 2004). For example, Ellen (2002, p. 242) argues that local populations engage in new knowledge (including scientific knowledge), sometimes transforming it in remarkable ways. Such a process is sometimes described as hybridisation, blending, etc., though defining what this might mean in formal and cognitive terms has proved elusive, partly because we cannot specify the 'units' or 'process' that are hybridising, and because recombination are intrinsic to all knowledge (ELLEN, 2002, p. 243)

The interests of social construction have led to actual debate between those who place more prominence on knowledge in development. The understanding of knowledge as a social construction contrasts with the rational, positivist view of knowledge derived from a western scientific viewpoint. As Kothari (2001, p. 141) argues knowledge is produced and is continually reformulated as a powerful normative construct. It implies that knowledge is an accumulation of social norms, rituals and practices that, far from being constructed in isolation from power relations, is embedded in them or against them.

Bouwen and Taillieu (2004, p. 146) argue, that from a social constructionist point of 
view, knowledge discourse is moving towards regarding 'knowledge as participation'. Knowledge creation, knowledge development and knowledge sharing are considered in this perspective as essentially relational processes, whereby people create knowledge by engaging in forms of participation in a community of practice. Knowledge sharing in natural resource projects is always situated in a context of practitioners, who enact this knowledge in their activities and their interactions. Following this dominant view of knowledge, a professional, a scientist or a manager is learning by participating in, creating and recreating continuously a particular community of practice.

Scientific knowledge is established as subject to essential changes in approach or paradigm shifts (KUHN, 1972, p. 43). Scientific knowledge has at times been described as universal, objective, testable, and verifiable. Methodologies are designed to be rigorous and the scientific community 'knows' the difference between good quality and bad quality science. However, the very nature of paradigm shifts acknowledges that scientific 'truth' is not universal (KUHN, 1972, p. 87).

From the modern western science perspective, scientists have historically maintained a dualistic relationship with nature in which detached observers gather empirical evidence to support theories about the natural world (NYGREN, 1999; BOWERS, 2001). Western science, in the positivist tradition, is considered nonbiased, objective and disconnected with human or spiritual values (STRINGER; REED, 2006). Bowers (1997, 2001) explains how western science, emerging from the enlightenment, is considered as high-status knowledge and maintains a human perspective of nature in which the individual, rather than the community, is the basic social unit (STRINGER; REED, 2006, p. 12). It means that western scientists avoid indigenous cultural traditions that obstruct 'progress' and embrace change as being inherently progressive in nature (BOWERS, 2001). The dualistic form of western consciousness contributes to the disassociation between humans and the environment. The cultural implications of this stance include the fact that western peoples are typically more detached from food resources, and other resources that nature provides
(BOWERS, 2001). In this way, development and knowledge are categories imposed by a western discourse to discipline and transform local realities (SCHONHUTH, 2002, p. 140). Economies are shaped on the foundation of information, learning and adaptation, and not only with the accumulation of physical capital (PURCELL; ONJORO, 2002). This involves shaping and adapting the systems to a given context, cultivating local learning processes, and institutionalising routines of use that persist over time. However, one of the requirements for the sustainability of technological projects in developing countries is that local knowledge is valued, sustained, and integrated in the process of implementation of new technologies (SCHONHUTH, 2002).

In contrast to modern western science, the term 'traditional ecological knowledge' adopts a more holistic framework as humans are viewed as intricately and spiritually interconnected with nature (CLEVELAND; SOLERI, 2002). For Posey (2000), over the past twenty years, indigenous peoples - together with their languages, cultures and knowledge systems - have become the focus of increasing international attention. This is the result of growing interest in the use of traditional knowledge held by local communities for the utilization of flora and fauna and in genetic resources, such as agricultural landraces and medicinal plants, held by indigenous peoples (POSEY, 2000, p. 35). Rooted in local culture, Purcell and Onjoro (2002) explain how traditional knowledge is a source of community cohesion, a framework that explains the origins of things, and provides the basis for preserving fertility, controlling pests, and conserving biological diversity and genetic variability. It is based on the idea that as indigenous people are directly dependent on the resources that nature provides for survival through sustenance living, they have a knowledge that is part of their experience (CLEVELAND; SOLERI, 2002, p. 206). Kalland (2000, p. 329) argues that although local people are recognized to have practised conservation consciously, their perceptions of nature have not operated to prevent pollution, or the destruction of natural resources. This author states that it is simplistic to assume that values and norms work directly on individuals, or acquire environmental actions as a corrobo- 
ration of specific values. When people have not destroyed nature this may have been the result of low population density compared to the resources and technologies available, rather than to consciously conserve resources.

The positivist tradition of western science is disengaged from human interests and values (COBURN; LOVING, 2001). On one hand there has been a disintegration of traditional values and forms of representation yet there has also been a progressive integration into the dominant culture of a scientific mentality and its values, knowledge content and patterns of action (SCHONHUTH, 2002, p. 140).

The notion of objectivity within western social and natural science implies that the researcher or rural environmental technician agent is merely an instrument, a conduit for information, rather than an interpreter and actor (CORNWALL et al., 1993, p. 8). In this notion, knowledge is often treated methodologically as if it could be built or destroyed, supplemented or supplanted (CORNWALL et al., 1993, p. 8). Bowers (2001) argues that a conventional approach based on knowledge as a commodity is limited in perceiving and responding to local people's concerns. Even though the majority of surveys aim to supply information for specialists to construct their own accounts of what people do, the surveys fail to identify with people's own accounts of their knowledge and practices (BOWERS, 2001, p. 18). The critical point is that conventional experimental design prioritises technical procedures rather than the complex dynamics of interaction between local people (CORNWALL et al., 1993; BOWERS, 2001). This can obscure the complex interactions that occur in changing social, economic and ecological environments. Moreover, the social constructionist approach does not take into account the relationship between knowledge production and types of discourse (SILLITOE, 2002b). Authors like Beck and Giddens bring their attention to the dangers of a technocratic society and the exclusion of local communities.

In the early 1990s, Giddens (1990) and Beck (1992) argued that we are moving towards a period of reflexive modernity, where modernity is becoming preoccupied with the struggle shaped by modernization itself. The second phase of modernity is marked by increasing awareness of risk, which is becoming a concern for the citizens and the base for political activity and mobilization. Risks are no longer limited in time and space; their consequences are very often global, and they extend to future generations (GIDDENS, 1990; BECK, 1992). As such, Sillitoe (2002b, p. 110) argues: "...we are not all the same, although the current trend towards a global culture is eroding the distinctions between different culturally- specific knowledge systems". This leads to a situation where recognition of current risks is based not on direct experience, but on institutionalised knowledge derived from expert assessment and administrative criteria, which tends to be invisible and abstract (BECK, 1992). Both Beck and Giddens perceive increasing individualization as a central aspect of modern society, and they attribute this to a new and more active political aspect. However, they have different positions. Beck centres attention on the environmental risks, while Giddens makes a more comprehensive analysis of the institutional dynamics behind the developments.

The development sector is beginning to recognise knowledge as a pillar of equitable and sustainable development and to view knowledge sharing as one of the central challenges for socio-environmental development practice (STRINGER; REED, 2006). The problem is that these practices are still based on an appraisal of corporate experiences with knowledge management. As Stringer and Reed (2006, p. 1) argue, the incorporation of integrated knowledge into socio-environmental programme requires much effort to institutionalise assessment methodologies and scientific techniques rather than to provide an accurate diagnosis or solution. For example, Kalland (2000) argues that there is much to learn from local environmental knowledge. However, there is not enough to secure a sustainable utilization of natural resources. It is necessary to formulate management regimes, which are based on local knowledge at the empirical and institutional level, while at the same time not ignoring the possible input from science. Knowledge management is about improving knowledge sharing within an organisation in order to construct new knowledge that enables the organisation to learn and innovate (KALLAND, 2000, p. 330). 
Learning as a social process strengthens the discussion of knowledge. It is the acquisition of knowledge through reflection, understanding and practice (VELDEN, 2002, p. 29). Here, learning is based on the premise that engagement in social practice is the fundamental process by which people learn to become who they are. The debate on learning is to bring new knowledge to the organisation to enable people to create better results for change. The problem is that development agencies have adopted approaches from the northern corporate sector and these approaches are inappropriate. This inappropriateness is identified by reason that these approaches see knowledge as a rootless commodity and information communication technology as a key knowledge tool (VELDEN, 2002, p. 1). The assumption that knowledge can be transformed into a commodity has entered the knowledge debate in the development sector. For example, Ellen (2002) demonstrates that knowledge is also linked with equity where a particular form of knowledge is favoured over others and to covey a further position. Similar impasses occur through commodities, whether preferences are exercised through the market, legal processes, or both (ELLEN, 2002, p. 243).

However, as the knowledge management discourse and methodologies expand to include the international development sector, significant problems of adaptation arise (MAHIRI, 1998, p. 2). For example, the World Bank outlines its role as a knowledge broker, transferring knowledge from where it is available to the place where it is needed (WORLD BANK, 1998). As critics have pointed out, this approach draws from the knowledgecentred ideas outlined above and perceives knowledge application as an objective and linear process (VELDEN, 2002). As Sillitoe (2002a, p. 1) argues, development agencies have been casting around for several years with mounting evidence of resources wasted in ill-conceived, frequently centrally-imposed schemes that have not only failed to matter in less developed countries but which have also made things worse. The World Bank's approach to knowledge obscures the plurality of alternative and legitimate knowledge (WORLD BANK, 1998). It is the ways in which people use information and integrate it into their knowledge that is more a function of people's capacities, opportunity, education, experiences, values and intuition, than the information than reaches them (VELDEN, 2002 , p. 6). If policy makers and managers wish to deal effectively with social problems they have to look at a number of areas: social, cultural, political, economic and environmental (DELANTY, 2003). The critique of the Bank's approach in this case indicates that knowledge needs to be presented in the appropriate context and be meaningful in the local situation in order to be useful and effective. The culture of analysis has provided ways of constructing an interdisciplinary dialogue to be incorporated into policy and public action. Culture has a political dimension, it is only one side of the human condition and of life in which knowledge of the human reality and the human interest in self-perfection and fulfilment merges into one (RAO; WALTON, 2004, p. 359).

In western terms, knowledge is a set of understandings that includes scientific knowledge as something unconnected from indigenous knowledge. The importance of indigenous knowledge about the environment and indigenous resource development reflects the recognition within the development policy community in the 1980s that indigenous knowledge could contribute to an increase in agricultural production and rural welfare (CHAMBERS, 1983). One dimension of this has been the increasing attention paid to indigenous management in diverse camps of social development (POSEY, 2000). The example of incorporation of local people into management positions presented by Chambers (1997) was an influential approach to contrast with the western understanding of rural people's knowledge. The introduction of participatory approaches reduces the dominance of standardised packages and the top-down models in which positivist and development blueprints are used. Despite incorporating local people's knowledge into programme planning as a significant part of participatory development (MOSSE, 2001, p. 17), it is not enough to change the top-down bureaucracy where the planning system is structured. Kothari (2001, p. 140) argues that within much participatory development discourse at local level, what is considered as local knowledge is seen as fixed commodities that people intrinsically have and own. 
The superiority of scientific knowledge pointed out by Chambers (1997) is the dominant idea that rural people are 'primitive', 'unscientific' and 'wrong'. This idea had influenced research and mechanisms used to educate and transform rural people's production and livelihood strategies. Although local knowledge is gaining wide recognition in western social science, is still associated with 'expert' or professional interpretation (MAHIRI, 1998, p. 527). Even with the recognition that local knowledge is innovative and dynamic, the experts play an advisory role in resource management, often putting policy into practice despite a deficiency of applied knowledge (MAHIRI, 1998, p. 28).

Local people have developed a broad-based knowledge of the environment, knowledge that is an accumulation of practical experience and experimentation (BEBBINGTON; FARRINGTON, 1997, p. 52). In Kenya, while experts are generally engaged in prototype monoculture and experimental projects, local villagers are more concerned with what can satisfy their needs (MAHIRI, 1998 , p. 2). This example demonstrates that although the participatory approach is applied as a comprehensive collaboration between experts and locals, the 'encounters' are too short to permit the evolution of a new relationship. The apparent monopoly of knowledge by 'experts' may then lead to intimidation of local people and an inhibition of the latter's free expression of their knowledge and views in the presence of 'experts' (MAHIRI, 1998, p. $3)$. Under such conditions, the discourses of development are produced by those in power and often result in reproducing power relations between areas of the world and certain people (POTTIER, 2003, p. 17).

Different and opposite point of views have been taken through the analysis of local knowledge within the 'development' context. It has been perceived as a major obstacle to development a panacea for environmental problems (INGLIS; HUGHSON, 2003), and as a critical component in locally-focused development (NYGREN, 1999). Local knowledge is generally viewed as distinct from scientific or western thinking. Thus, local and scientific knowledge have often been seen in static opposition, two forms of discrete, bounded knowledge (VELDEN, 2002). However, these static oppositions of local versus universal knowledge have been questioned. Local people do not live in isolation; knowledge develops through experimentation and experience, from working with rural technician officers, or talking to people with different experiences and so forth. There is for that reason, a requirement on behalf of government to establish more diversified models of understanding knowledge at local level (NYGREN, 1999). As Velden (2002, p. 34) argues, the development processes in which knowledge is created, accessed and used, need to acknowledge and incorporate the diversity of both the knower and culture in these processes.

The view of knowledge presented by Cornwall et al. (1993, p. 4) is that the social networks to which people's knowledge belong interact in many domains, creating complex knowledge chains about issues and innovations. If knowledge is understood as socially constructed, the focus of examination can be on the processes that legitimise certain hierarchies of knowledge and power between local and global (scientific) knowledge (NYGREN, 1999). However, the conventional representation of local knowledge as being in opposition to modern knowledge is problematic. It is because it does not allow for the recognition of diversity within different people's knowledge repertories and inherently privileges one form of knowledge over another. Local communities are changing in the interactions of its members not only amongst each other, but increasingly are evolving rapidly (CRAPS et al., 2004, p. 388).

As local knowledge is often seen as location-specific and therefore fixed and rigid rather than fluid and dynamic (ESCOBAR, 1995; ELLEN, 2002), less attention has been given to the cross-characteristics of such knowledge and to the idea that local people produce shared knowledge (NYGREN, 1999). As is argued by Bauman (2001), a constructive route is one that attributes more power to local communities, to use local knowledge as the starting point of the analysis. The local is constantly constructed and reconstructed according to the dynamic process of social, economic and policy actions.

Cultural and knowledge aspects through the practice of political action have become the dominant pattern in socio-environmental 
development programmes in the last decade (SILLITOE, 2002b). In spite of a range of terms used to refer to local people, it is important to identify when this knowledge is indigenous (SILLITOE, 2002b). As Ellen (2002, p. 239) argues, indigenous knowledge in a development context may relate to any knowledge held more or less collectively by a population. The distinction between indigenous and scientific, local and global knowledge is defensible and different (SILLITOE, 2002b). However in Sillitoe (2002a, p. 12), what is made of the differences apparent between scientifictechnical and indigenous knowledge depends on one's view of development. Indigenous or local knowledge and modern, scientific knowledge have become increasingly separated in the process of modernisation, and have often been assumed to be fundamentally different (ELLEN, 2002).

In sum, the influence of science as highstatus knowledge sustains a human perspective of nature in which the individual, rather than the community is prioritised. In this way, the western scientists avoid indigenous cultural traditions that obstruct 'progress' and embrace change as being inherently progressive in nature. It brings attention to the idea that production of knowledge in a global world is based on institutionalised knowledge derived from expert assessment and administrative criteria that is involved in a new and more active political sphere. It also obscures those who interact in changing social, economic and ecological environments through complex relations. However, the focus on micro-level analysis reinserts the term community to refer a specific space that is produced and provides people with the opportunity to develop their active citizenship. Knowledge as a commodity is limited in perceiving and responding to local people's concerns since it has no interest in identifying with people's own accounts of their knowledge and practices (RAO; WALTON, 2004, p. 361-2). However, a model of the social process of transforming commodities into conditions of well-being is a long way on from a catalogue of goods that are universally supposed (DOUGLAS, 2004, p. 105). A change from a focus on individuals to a recognition that relational and group-based interests shape and influence individuals' aspirations, capabilities, and distribution of power and agency (RAO; WALTON, 2004, p. 359). However, to be aware of local conceptions of well-being, and to incorporate 'common sense' and 'voice', the recipients of public action require to be engaged as central agents in the configuration and implementation of policy. It entails that the theory and practice of development will be more complex and, inevitably, more participatory (RAO; WALTON, 2004, p. 361).

\section{The Meaning of Culture in Development}

In recent years, academic interest in culture in public action and a range of ideas about the nature of culture has increased (RAO; WALTON, 2004; SEN, 2004). In the world of policy, culture is increasingly being viewed as a commonplace, malleable fact of life that matters as much as economics or politics to the process of development (RAO; WALTON, 2004, p. 3). Douglas (2004) argues that development works always to destabilise a fragile balance of social forces. It involves a risk if as Douglas (2004) argues it is going to erode the community's accumulated store of trust, and dissolve their traditional readiness to collaborate. In this way the well-being of the community may be worse after development than before (DOUGLAS, 2004, p. 89).

Rao and Walton (2004) point out two extreme views tend to dominate the rhetoric on culture and development. There is the hypermodist perspective that culture matters because societies steeped in traditional cultures are unsuited to market-oriented development fundamentally in growth issues. Culture is viewed as the enemy that inhibits societies from functioning in the modern world. This second modernization viewpoint was formed by some traditional economists and has dominated development since the 1950s. As Rao and Walton (2004, p. 10) argue, dominance is viewed as an aspect of control in western ideologies and interests. It implies that culture is a system of control that creates and expands existing macro inequalities between rich and poor countries, and macro inequalities between westernised and indigenous groups in poor countries (RAO; WALTON, 2004, p. 11).

For Sen (2004, p. 37), the key issue is to investigate the different and diverse ways in which culture should be taken into account in 
examining the challenge of development, and in assessing the demands of sound economic strategies. And also how can these influences be better understood, and how might they modify or alter the development policies? In this way, Rao and Walton (2004) recognise that there is a culture of development associated with dominant mainstream economic views in the development discourse, and has had a powerful, and not always positive, effect on the world's poor countries. However, the focus is on how to integrate notions of culture and socioeconomic change to design more effective public action. This point of view is different from that as culture as static which has a simplistic view of the development problem in which culture is treated as an exogenous constraint rather than as one of the realms of everyday life (RAO; WALTON, 2004, p. 11). However, culture is not a 'natu$\mathrm{ral}^{\prime}$ matter that is unchangeable and static (KLAMER, 2004, p. 140); on the contrary, it comprises the patterns of ideas, values, practices, and beliefs common to a particular group of people, or a set of people within a particular society (INGLIS; HUGHSON, 2003; KLAMER, 2004).

The existence of dynamics within the cultural space where the notion of relationship among various 'world views' make possible an analysis of the power differences that take place between the parties involved (LONG; VILLARIAL, 1996; POTTIER, 2003). It is important here to point out the recognition that all societies contain within them a repertoire of different life styles, cultural forms and rationalities which members utilize in their search for order and meaning, and which they themselves play a part in affirming or restructuring. Long (1992, p. 25) raised a further issue related to the cultural forms. The strategies and cultural constructions employed by individuals do not arise out of the blue but are drawn from a stock of available discourses that are to some degree shared with other individuals, contemporaries and perhaps predecessors. As Inglis and Hughson (2003, p. 3) argue, the most important issue is to understand how these cultural factors contribute towards either the maintenance or the overthrow of the status quo in that society. It means that the incorporation of culture in policy space is not just to understand the relationship between groups or between societies, but also to comprehend what goes on, especially in terms of wielding power within particular groups and societies (RAO; WALTON, 2004).

Culture is involved in power relations and reflects acts of producing knowledge (POTTIER, 2003). However, as Inglis and Hughson (2003, p. 3) have argued, the key point is to analyse how cultural factors contribute towards changes in society. The nature of changes is complex and challenges the relations between time and space. Bauman (2001) explains changes that are now more disorderly and entangled than in any preceding epoch. It is because things today are moving sideways, aslant or across rather than forward, often backward, but as a rule the movers are unsure of their direction and the nature of successive steps is hotly contested (BAUMAN, 2001, p. 137). From Bauman's point of view, coexistent life-forms mean that they settle aside each other, clash and mix, and crowd together in the same space/time (BAUMAN, 2001, p. 137).

Lash (1999) puts forward a different point of view to define culture. He describes the world of global information culture as "a swirling vortex of microbes, genes, desire, death, semiconductors, holograms, semen, digitised images, electronic money and hyperspaces in a general economy of indifference" (LASH, 1999). He highlights that the world is shifting from a primary epistemological modernity where knowing subjects constructed the objects of knowledge, to a second or reflexive modernity of ontology where objects themselves have become possessed of being. The rise of the global information culture shifts the world again, to somewhere else yet to be configured, but somewhere that sees human singularity decline as these objects begin to think (LASH, 1999). It is the age "of the inhuman, the post-human and the non-human, of biotechnology and nanotechnology" (LASH, 1999) of an object material culture in which technologies, objects of consumption, lifestyles, come to dominate the cultural landscape and take on the power to constitute, track and judge.

The explanation of the shift from cultural features to rapid changes by Bauman (2001) and Lash (1999) make it clear that 
the world is facing increasing ranges of complexities under rapid transformation. For Bauman, the difficulty is to capture the realities of our age, since the defining traits of post-modernity's coexistent life forms are uncertainty and ambivalence, and permanently unfinished differentiation (LONG, 1992; BAUMAN, 2001).

Culture provides for the members of a society a conceptual universe that both frames and constructs patterns of behaviour as mutually constitutive (BERGER; LUCKMANN, 1966). Culture provides the shared knowledge system that enables members of a society to recognize fellow members and to coordinate their actions with one another (Read, 2003, p. 32). Society provides the communities with points of views, and thus the patterned interactions and experiences, out of which individuals construct their representations of culture (BERGER; LUCKMANN, 1966; READ, 2003). This constitutive property of culture underscores the reason that theorizing in anthropology has focused on culture as central for understanding the nature of human societies (READ, 2003, p. 33). Analysis of the kinship basis of the social organization of rural communities reveals the role of kinship in the economic, political and religious organization of rural settlements (AIRES, 1992). Aires demonstrates that while religion constitutes a basis for the constitution of community identity, religious practice does not constitute a basis for the formation of a symbolic identity at local level. For example, religion both creates links between caboclos and other social categories which follow the same religion and differentiates between caboclos with different religious identities. Aires's work is important to understand that the lack of involvement in a political movement is the reason for the absence of a collective identity among caboclos (AIRES, 1992, p. 45).

Despite the centrality of culture as an organizing concept, satisfactory theories about the relationship between behaviour and culture has continued to be obscure (INGLIS; HUGHSON, 2003). Consequently, current theories of cultural evolution are incomplete because "no theory of socio-cultural evolution can claim completeness if it is not able to define the generating logic of society and socio-cultural evolution (READ, 2003, p. 32). Theoretical positions differ on even a basic issue such as whether we understand culture as arising from human behaviour taken as actions in response to an evaluation of conditions and consequences external to the individual or whether behaviour already presupposes culture so that behaviour can be seen as arising from acting out of actions suitable to the cultural identity the individual takes on.

The socio-cultural aspect adds other arguments to explain the meaning of culture. The increased debate from socio-cultural perspectives demonstrates the transforming and complex changes in the world (READ, 2003). However, the majority of attention has been focused on cross-cultural changes (GREDLER, 1997, p. 23) and on different life-worlds that interact. These authors agree that the increasing interest in diversity is a consequence of the complex transformation encounters of the globalizing world. Globalisation has meant that at the local level, the world's peoples are closer together ensuring that diversity, plurality, hybridism, dislocation and discontinuity have become a recurring theme (GREDLER, 1997, p. 24).

Perlow and Weeks (2002) further investigate the role culture plays in shaping how helping behaviour is framed and when it is performed in a given context. They use groups of Americans and Indians as a point of comparison of national culture and these two cultures form a useful contrast for studies of helping behaviour. The focus on these two cultures is justified for the differences between the general Indian culture with its emphasis on interdependence and mutual aid and the American cultural emphasis on the individual (WEEKS, 2002). Through the comparative method, Perlow and Weeks (2002) conclude that American culture is highly individualist whereas Indian culture is more collectivist. Individualistic cultures are characterized as emphasizing the importance of individuals maintaining their independence and differentiating themselves from other people. Collectivist cultures are characterized as emphasizing the importance of interdependence between people and the way in which individual identity is defined by one's relationship to others (GREDLER, 1997; DOUGLAS, 2004). 
This means that the incorporation of culture in policy space is not just to understand the relationship between groups or between societies, but also to comprehend what goes on, especially in terms of wielding power within particular groups and societies (INGLIS; HUGHSON, 2003). As is demonstrated by Rao and Walton (2004, p. 3), even though culture assumes a 'commonplace' in policy space, there remains some confusion about how it matters (RAO; WALTON, 2004, p. 3). In this paper, the researchers offer a contribution to the debate by stressing how culture is taken into account in the process of development that also involves knowledge. The framework towards these two concepts should be examined as interconnected, a key element to identify the impact of development programmes on local communities. Although the Brazilian government created a policy to interact with local communities, the challenge is how to invest in strategies to have a positive impact on people's livelihoods.

\section{Knowledge and Culture}

Culture is embodied in the symbols and artefacts of human interaction activities (BERGER; LUCKMANN, 1966; READ, 2003). People are involved in networks that contribute to the circulation of information among groups of people (ABRAHAM; PLATTEAU, 2004 , p. 229). From this point of view, culture is embedded in the social process, and reflects acts of producing knowledge (POTTIER, 2003). Culture is involved in the notion of relationships attributed to the relations among individuals within groups, among groups that share ideas and perspectives (RAO; WALTON, 2004; SEN, 2004).

Knowledge results from interactions between people and their environments and resides within culture (HABERMAS, 1971; LONG; VILLAREAL, 1996). However, the construction of knowledge is also influenced by the cultural and historical factors of the community (WEEDON, 2004, p. 23). When the members of the community are aware of their 'intersubjective' meanings, it is easier for them to understand new information and activities that arise in the community. 'Intersubjectivity' relates to a shared understanding among individuals whose interaction is based on common interests and assumptions that form the ground for their communication (JACKSON, 1996; MIDGLEY, 2000). 'Intersubjectivity' not only provides the grounds for communication but also supports people to extend their understanding of new information and activities among the group members (UPHOFF et al., 1998, p. 133).

Midgley (2000) develops an argument about the implications of mechanistic versus systemic assumptions about relationships across the three worlds. The three worlds refer conceptually to the (i) subjective, psychological personal world of perceptions, based on interpretation by the senses, lived experience and tacit knowledge; (ii) the objective, external natural world of professional knowledge narratives based on observation; (iii) the social or intersubjective world based on shared meaning that is co-created through dialogue. In the social world, at worst we misunderstand each other completely or at best work harmoniously to co-create meaning. Midgley (2000) uses these three worlds as a starting point for addressing the connection across representation, communication and reality. Each world has implications for policy and practice (management, leadership, research and the way in which problem solving is approached). Jackson (1996) applied the three worlds to develop a meta-level approach to working with management models. He places importance on the links across the areas of knowledge rather than on technical knowledge. This reinforces Habermas's (1971) viewpoint that knowledge connects with three camps: technical, strategic and communicative knowledge. However, the challenge is to work with diversity and to manage it. Uphoff et al. (1998) argue that increasing attention has been devoted to management information systems that handle the large amounts of data and information that programme generate and require. The information can be shared with the process of dissemination producing mutations that can enhance or degrade the information in circulation (UPHOFF et al., 1998, p. 135).

Construction of social meanings also involves intersubjectivity among individuals and organisations. Social meanings and knowledge are shaped and evolved through negotiation within the communicating 
groups (HABERMAS, 1971; WEEDON, 2004). Personal meanings shaped through these experiences are affected by the intersubjectivity of the community to which the people belong (WEEDON, 2004, p. 19). The sense of belonging and connectedness is characterized by the perception of territorial borders, by the recognition of strong historical significance, and by a dimension that is attributed to the place or community. A sense of community is related to belonging and connectedness and this has to be taken into account. Indeed, this sense remains prominent often in the course of conducting research on political action at local level.

Cultural conditions exert considerable influence upon human behaviours, not only in the social sphere, but also in the economic (SEN, 1999). In spite of many definitions of 'development' that focus on economic aspects, it is fundamental to recognise its social and cultural elements (SEN, 1999; WILLIS, 2005). This is not just because social and cultural variables affect economic growth, but also that social and cultural norms and expectations need to be considered in their own right (WILLIS, 2005, p. 116). As Sen (2004, p. 43-4) argues, if development relates to the increase or improvement of living standards through social and economic change, then it will impact on, and be mediated through culture.

The concept of culture has until recently been ignored by development theorists who were eager to escape colonial discourses of culture and the 'culturalist' explanations of modernization which represented culture as a 'barrier' to development (HARRIS, 1996; IVANOVA, 2005). This aversion to addressing culture too often leads development studies (even those preoccupied with institutional arrangements and incentive structures) to ignore the complexity and diversity of human life. It also neglects the way in which culture is a dimension of all social action, including economic and political life (SEN, 1999, 2004; RAO; WALTON, 2004).

The increased occurrence of organizations operating across national boundaries, and the embracing of cultural diversity as a business strategy, represent a variety of recent trends. The convergence of these trends corroborates the membership of groups, becoming more culturally diverse (IVANOVA, 2005). If organizations are to be successful, they need managers to have an awareness of the impact of increasing cultural diversity (Küpçü, 2005). Despite the importance of this need for organizational success, the current literature has done little to enhance managers' knowledge of how effectiveness might be impacted when cultural diversity modifies or alters local knowledge. Harris (1996, p. 34) challenges this gap in examining cultural diversity and its impacts on group effectiveness.

If the analysis includes organizational culture, the focus on the context where the interaction occurs is significant because organizations are part of societal structures and sets of meanings (HARRIS, 1996; TENDLER, 1997). Harris (1996, p. 34) argues that the issues around management, racism, professionalism, class, for example, are meanings embedded in broader structures of social power. However, the interpretations of organizations cannot be simply reduced to those meanings and power structures in broader society as tends to happen. The literature on organizational culture is a helpful corrective to this take on organizations, for analysis of the ways in which meanings are constructed within development organizations. However, such meanings are both stabilized and fragmented over time. It is only through studying practices that one can understand the ways in which organizations tend towards having a more or less integrative or fragmentary culture shared by staff or it is only through a study of practice that it becomes possible to understand how and why organizations are given the meanings that they are given by people beyond the organization.

The main factor for influential organizational processes is the requirement to act in response to pressures from upwards such as funding agencies and downwards such as community groups. The different structures and capabilities developed by organizations to maintain unity and integrity in response to these tensions are explored and related to differences in the perceived role of the organizations. These tensions are between the bureaucratic structures that initiate and fund development projects and the grassroots organizations that can mobilize participation and resources to implement them (INGLIS; 
HUGHSON, 2003; ALKIRE, 2004). Although large-scale development agencies recognize the need for local participation to facilitate project implementation and local organizations recognize the need for centrally-provided resources to support and expand their local activities, the organizational gulf between the two precludes effective interaction.

Tendler's work (1997) is also relevant to understand the influence of culture on development for agencies and for local people. Tendler's study of the sources of effective government in the north-east of Brazil aims at an understanding of how innovation had occurred within several government programmes in Ceará State. It focuses on the actions of bureaucrats and project staff along the chain of project implementation to understand what led officials and staff to act in ways that favoured client orientation, responsiveness and programme effectiveness. Such concerns led to an analysis of explaining the changes in organizational incentives and behaviour that led to effective programmes. Tendler's analysis focused on specific innovators and individuals who had taken risks within bureaucracies and who had often had the authority to effect change.

The cultural impact of development agencies and interventions - both positive and negative - has been a much-mooted topic within development in recent years (RAO; WALTON, 2004, p. 3). In this respect, culture, knowledge and development interconnect at many intersections that relate to both a means and an end and in a complexity of ways (SEN, 1999; 2004). In any particular domain such as social or economic development, several knowledge systems exist, some of which, consensually through a 'constellation of interests' (CASTELLS, 1997, p. 12), come to acquire more value than others. They explain the reality better for immediate purposes or they emanate from a stronger power base. An inexorable consequence of the legitimating of one kind of knowledge as authoritative is the devaluation and discharge of other kinds of knowledge. It means that "cultural diagnoses cannot provide universally applicable answers. Culture is part of the story - part of the formation of agency, of effective markets and institutions - but is often left out" (RAO; WALTON, 2004, p. 360).
The devaluation of traditional cultural knowledge systems is a general mechanism by which hierarchical knowledge structures and resulting 'cultures of development' are generated, transmitted, valorised and implemented (INGLIS; HUGHSON, 2003, p. 26). Rather than viewing culture as an attribute of the societies undergoing development (SCHECH; HAGGIS, 2000, p. 42), the new ways of thinking about culture and development mean examining how development institutions, processes and practices are caught up in a web of cultural presuppositions, values and meanings (SCHECH; HAGGIS, 2000, p. 42-3).

The cultural aspect assumes an important role in public actions, mainly in a heterogeneous environment where these pursuits of diversity, of identity and social practices involve local people with their own knowledge and aspirations (LONG, 1992; RAO; WALTON, 2004). This is a position where culture is not a homogenous and stable attribute (SCHECH; HAGGIS, 2000) since it is involved in many aspects. Heterogeneity can also arise from the particular components of culture for instance religion, literature or style of living (SEN, 2004). This is a framework of culture as a component of a set of capabilities that people have - the constraints, technologies, and frame-working strategy that state how decisions are made and co-ordinated across diverse actors (SEN, 1999; RAO; WALTON, 2004). Bourdieu (1993) identifies styles/values, preferences/aspirations as cultural issues that are accumulated through a long process of acquisition. In this understanding, cultural capital is a base resource of vital importance in the formation of other forms of resource e.g. natural, human, or social capital, and indeed the long-term sustainability of any human or economic development initiative (ARCE, 2003; KAPOOR, 2004).

Arce $(2003$, p. 6) argues the importance of reversing traditions of the treatment of the social as resulting from economic development. This point of view calls for a new perspective that goes beyond a theoretical identification of social development with the management of resource scarcity. However, with the advent of participatory thinking and empowerment, development is today typically represented as an outcome of peoples' 
actions (ARCE, 2003). For Sillitoe (2002b), the new third way for the twenty-first century is an action approach, as opposed to a purely academic one. Although the previous approaches were blind to local knowledge, the new emergence of development's interest in indigenous knowledge and practices is seen as new, bottom-up oriented development paradigm (SILLITOE, 2002b, p. 115).

The expression of action is to understand the rapidly changing world. This shift in representation has contributed to identifying the social as mainly related to techniques of participatory planning and methodologies for consultation and incorporation (ARCE, 2003 , p. 7). Such a shift provides scope for planning without actually allowing the social to break free from priorities dictated by the economic management of the scarcity of resources (ARCE, 2003, p. 7). Despite the debate on the understandings that 'the social' can encompass the creativity of people's knowledge and practices since the 1980s (BOOTH, 2003) the emphasis on people's knowledge is still a challenge. The argument is based on the possibility of challenging existing social, cultural, and political boundaries through the internalisation of a development language such as participation and empowerment within people's everyday life. This process was presented not just as adaptation, but also as a qualitative change into new situations. It created a window for social development that has been incorporated into dominant economic discourse as a representation of the social (CHAMBERS, 1983, p. 21).

Studies made by Rao and Walton (2004), emphasises a positive impact by incorporating the cultural aspect into a development context and emphasising the importance of culture on public actions. Culture is seen as having an important role in policy development and is present mainly in heterogeneous environments where pursuits of diversity of identity and social practices involve local people with their own knowledge and aspirations (SILLITOE, 2002b; SCHECH; HAGGIS, 2000). However, the focus is on the analysis of how knowledge is produced and the influence of power relations on the production of knowledge.

\section{Concluding remarks}

Despite all consideration of interconnectedness over the concepts of knowledge and culture, what is more important is to understand knowledge as a component of power that is transferred from one social context to another within a system of value and beliefs. Knowledge, as a component of power, is an accumulation of social norms, rituals and practices that are culturally, socially and politically produced as a powerful normative construct.

Instead of understanding culture as a dynamic, social construct with power relations, cultural aspects have just been assumed to have a positive impact on public actions. The positive idea is that culture provides a vehicle for building public action in development and for the implementation of sustainable policies with more inclusive and long-term strategies. This means that culture in development is particularly important to an adequately capacious framework suggested by Sen (2004).

The aim of using a framework that involves knowledge and culture within a development context is to examine the impact of government programme actions in the local communities. If development relates to increasing or improving living standards through social and economic change, then it will impact on, and be mediated through culture. If culture in development is understood as a process of social change with shared values, aspirations and ideas, the questions to be asked are: How do 'development' interventions provide for or invest in communities with the relevant cultural knowledge required to successfully participate in their own development livelihood? Is the policy action receptive to the proposals and priorities of the local people?

The central issue of the framework proposal is to examine the key feature of governmental development programmes in implementing policies at local level. We argue that the complex interaction between programme and policy development and local people emerges as a new challenge in the participatory policy model. It is difficult however to fill the gaps opened up for participation through the engagement of people in 
policy issues. A great deal of the framework presented is to illustrate understanding of how a macro-level programme geared towards change in the micro-level can result in a positive impact on community development livelihoods taking into account the concepts of knowledge and culture.

\section{References}

ABRAHAM, A.; PLATTEAU, J.-P. Participatory development: where culture creeps. In: RAO, V.; WALTON, M. (Ed.). Culture and public action. Stanford: Stanford University Press, 2004. p. 212-233.

AIRES, D. L. The social category caboclo: history, social organization, identity and outsider's social classification of the rural population of an Amazonian region (the middle Solimões). PhD. Cambridge: Cambridge University, 1992.

ALKIRE, S. Culture, poverty, and external intervention. In: RAO, V.; WALTON, M. (Ed.). Culture and public action. Stanford: Stanford University Press, 2004. p. 185-209.

ARCE, A. Re-approaching social development: a field of action between social life and policy processes. International Development, (15): 845-861, 2003.

BAUMAN, Z. Community: seeking safety in an insecure world. Cambridge: Polity Press, 2001.

BEBBINGTON, A. J.; FARRINGTON, J. NGO-government interaction in agriculture technology development. In Edwards, M. and Hulme, D. (Ed.) Making a difference: NGOs and development in a changing world. London: Earthscan Publications, 1997. p. 49-59.

BECK, U. Risk society: towards a new modernity. London: Sage Publications, 1992.

BERGER, P.; LUCKMANN, T. The social construction of reality. New York: Doubleday, 1966.

BOOTH, D. Bridging the macro - micro divide in policyoriented research: two African experiences. In: EADE, D. (Ed.) Development methods and approaches - critical reflections. London: Oxfam, 2003. p.79-94.

BOURDIEU, P. The field of cultural production - essays on art and literature. Cambridge: Polity Press, 1993.

BOUWEN, R.; TAILLIEU, T. Multi-party collaboration as social learning for interdependence: Developing relational knowing for sustainable natural resource management. Journal of Community $\mathcal{E}$ Applied Social Psychology, 14(3): 137-153, 2004.

BOWERS, C. A. The culture of denial. New York: State of New York Press, 1997.

. Educating for eco-justice and community. Athens: The University of Georgia, 2001.

CASTELLS, M. The power of identity, the information age: economy, society and culture. Oxford: Blackwell, 1997.

CHAMBERS, R. Rural development: putting the last first. London: Longman, 1983.
Whose reality counts? Putting the first last. London: Intermediate Technology Publications, 1997.

CLEVELAND, D. A.; SOLERI, D. Indigenous and scientific knowledge of plant breeding. In: SILLITOE, P.; BICKER, A.; POTTIER, J. (Ed.). Participating in development: approaches to indigenous knowledge. London and New York: Routledge, 2002. p. 206-234.

COBURN, W. W.; LOVING, C. C. Defining science in a multicultural world: implications for science education. Science Education, 85 (1): 50-67, 2001.

CORNWALL, A. et al. Acknowledging process: challenges for agricultural research and extension methodology. Brighton: IDS, 1993.

CORNWALL, A. Realizing rights: transforming approaches to sexual and reproductive well-being. London and New York: Palgrave and Zed Books, 2002.

CRAPS, M. et al. Constructing common ground and re-creating differences between professional and indigenous communities in the Andes. Journal of Community $\mathcal{E}$ Applied Social Psychology, 14 (5): 378-393, 2004.

DELANTY, G. Community. New York and London: Routledge, 2003.

DOUGLAS, M. Traditional culture - let's hear no more about it. In: RAO, V.; WALTON, M. (Ed.). Culture and public action. Stanford: Stanford University Press, 2004. p. 85-109.

ELLEN, R. Reinvention and progress in applying local knowledge to development. In: SILLITOE, P.; BICKER, A.; POTTIER, J. (Ed.) Participating in development: approaches to indigenous knowledge. London and New York: Routledge, 2002. p. 235-258.

ESCOBAR, A. Encountering development: the making and unmaking of the third world. Princetown: Princetown University Press, 1995.

GAVENTA, J. Towards participatory governance: assessing the transformative possibilities. In: HICKEY, S.; MOHAN, G. (Ed.). Participation: from tyranny to transformation? Exploring new approaches to participation in development. New York: Zed Books, 2004. p. 25-41.

GIDDENS, A. Consequences of modernity. Cambridge: Polity Press, 1990.

GREDLER, M. Learning and Instruction: theory into practice. New York: Prentice-Hall, 1997.

HABERMAS, J. Knowledge and human interest. London: Heinemann, 1971.

HARRIS, M. People of the Amazon floodplain: kinship, work and sharing in a "caboclo" community near Óbidos, Pará, Brazil. PhD. London School of Economics and Political Science, 1996.

INGLIS, D.; HUGHSON, J. Confronting culture: sociological vistas. Cambridge: Polity Press, 2003.

IVANOVA, M. Environment: the path of global environmental governance - from and function in historical perspective. In: AYRE, G.; CALLWAY, R. (Ed.). Governance for sustainable development. London: Earthscan Publications, 2005. p. 45-72.

JACKSON, C. Gender and participation at a project interface. Public Administration and Development, 16(5): 503-511, 1996. 
JACOBS, M. Environmental modernisation: The new labour agenda. London: The Fabian Society, 2002.

KALLAND, A. Indigenous knowledge: prospects and limitations. In: ELLEN, R.; PARKERS, P.; BICKER, A. (Ed.). Indigenous environmental knowledge and its transformations. London: Harwood Academic Publishers, 2000. p. 319-335.

KAPOOR, I. Donor participatory governance evaluation: initial trends, implications, opportunities, constraints. Journal of International Development, (16): 157-170, 2004.

KLAMER, A. Cultural goods are good for more than their economic value. In: RAO, V.; WALTON, M. (Ed.). Culture and public action. Stanford: Stanford University Press, 2004. p. 138-162.

KOTHARI, U. Power, knowledge and social control in participatory development. In: COOKE, B.; KOTHARI, U. (Ed.). Participation: the new tyranny? London and New York: Zed Books, 2001. p.139-152.

KUHN, T. The structure of scientific revolutions. Chicago: University of Chicago Press, 1972.

KUKLA, A. Social constructivism and the philosophy of science. New York: Routledge, 2000.

KÜPÇÜ, M. F. Society: participation and engagement. In: AYRE, G.; CALLWAY, R. (Ed.). Governance for sustainable development. London: Earthscan Publication, 2005. p. 90-107.

LASH, S. Another modernity, a different rationality. Oxford: Blackwell Publishers, 1999.

LONG, N. From paradigm lost to paradigm regained? The case for an actor-oriented sociology of development. In: LONG, N. (Ed.). Battlefields of knowledge. London: Routledge, 1992. p. 16-43.

LONG, N.; VILLARREAL, M. Exploring development interfaces: from the transference of knowledge to the transformation of meaning. In: SCHURMAN, F. (Ed.). Beyond the impasse: new directions in development theory. London and New York: Zed Books, 1996.

MAHIRI, I. O. The environmental knowledge frontier: transects with experts and villagers. Journal of International Development, 10: 527-537, 1998.

MIDGLEY, G. Systemic intervention: philosophy, methodology and practice. London: Kluwer, 2000.

MOSSE, D. People's knowledge, participation and patronage: operations and representations in rural development. In: COOKE, B.; KOTHARI, U. (Ed.). Participation: the new tyranny? London and New York: Zed Books, 2001. p. 16-35.

MUTEBI, F. Reassessing popular participation in Uganda. Public Administration and Development, 29: 289-304, 2004.

NYGREN, A. Local knowledge in the environmentdevelopment discourse. From dichotomies to situated knowledges. Critique of Anthropology, 19(3): 267-288, 1999.

PERLOW, L.; WEEKS, J. Exploring the relationship between decision making and the temporal context. Academy of Management Journal, 45 (5): 931-955, 2002.
POSEY, D. A. Ethnobiology and ethnoecology in the context of national laws and international agreements affecting indigenous and local knowledge, traditional resources and intellectual property rights. In: ELLEN, R.; PARKERS, P.; BICKER, A. (Ed.). Indigenous environmental knowledge and its transformations - critical anthropological perspectives. Amsterdam: Harwood Academic Publisher, 2000. p. 35-54.

POTTIER, J. Negotiating local knowledge: an introduction. In: POTTIER, J.; BICKER, A.; SILLITOE, P. (Ed.). Negotiating local knowledge: power and identity in development. London: Pluto Press, 2003.

PURCELL, T.; ONJORO, E. A. Indigenous knowledge, power and parity. In: SILLITOE, P.; BICKER, A.; POTTIER, J. (Ed.). Participating in development: approaches to indigenous knowledge. London and New York: Routledge, 2002. p.162-188.

RAO, V.; WALTON, M. Culture and public action. Stanford: Stanford University Press, 2004.

READ, D. From behaviour to culture: an assessment of cultural evolution and a new synthesis. Community $\mathcal{E}$ Applied Social Psychology, 8(6): 17-41, 2003.

SCHECH, S.; HAGGIS, J. Culture and development: a critical introduction. Oxford: Blackwell Publishing, 2000.

SCHONHUTH, M. Negotiating with knowledge at development interfaces. In: SILLITOE, P.; BICKER, A.; POTTIER, J. (Ed.). Participating in development: approaches to indigenous knowledge. London and New York: Routledge, 2002. p. 139-161.

SEN, A. Development as freedom. Oxford: Oxford University Press, 1999.

How does culture matter? In: RAO, V.; WALTON, M. (Ed.). Culture and public action. Stanford: Stanford University Press, 2004. p. 37-58.

SILLITOE, P. Participant observation to participatory development. In: SILLITOE, P.; BICKER, A.; POTTIER, J. (Ed.). Participating in development: approaches to indigenous knowledge. London and New York: Routledge, 2002a. p. 1-23.

Globalizing indigenous knowledge. In: SILLITOE, P.; BICKER, A.; POTTIER, J. (Ed.). Participating in development: approaches to indigenous knowledge. London and New York: Routledge, 2002b. p. 108-138.

STRINGER, L. C.; REED, M. S. Land degradation assessment in southern Africa: integrating local and scientific knowledge bases. Land Degradation \& Development, v. 18, Issue 1, 2006. Available in: <http://onlinelibrary. wiley.com/doi/10.1002/ldr.760/abstract>. Accessed in: 22 Nov. 2006.

TENDLER, J. Good government in the tropics. Baltimore: Johns Hopkins University Press, 1997.

UPHOFF, N. et al. Reasons for success - learning from instructive experiences in rural development. New Delhi: Vistaar Publications, 1998.

VELDEN, M. V. D. Knowledge facts, knowledge fiction: the role of ICTs in knowledge management for development. International Development, 14: 25-37, 2002. 
WEEDON, C. Identity and culture: narratives of difference and belonging. Milton Keynes: Open University Press, 2004.

WILLIS, K. Theories and practices of development. London and New York: Routledge, 2005.
WORLD BANK. World development report 1998/99: knowledge for development. Washington, D.C.: World Bank, 1998. Available in: <www.worldbank.org/wdr98/ index.htm>. Accessed in: 22 Jan. 2004. 